\title{
Ewa Solarczyk-Ambrozik (red.), Całożyciowe uczenie się jako wyzwanie dla teorii i praktyki edukacyjnej, Wydawnictwo Na- ukowe UAM, Poznań 2013, ss. 479
}

Prezentowana pozycja odpowiada na nowe procesy, problemy i zadania w obszarze teorii i praktyki kształcenia ustawicznego. Jest zbiorem trzydziestu jeden artykułów, których analiza pokazuje różnorodność i złożoność podejmowanych w nich problemów oraz wielowątkowość dyskursów dotyczących edukacji całożyciowej. Jest prezentacją podstawowych kierunków namysłu nad teorią i praktyką edukacyjną podejmowanych w różnych ośrodkach akademickich i instytucjach praktyki edukacyjnej oraz źródłem wiedzy na temat badań i dobrych praktyk dotyczących różnych obszarów kształcenia ustawicznego i edukacji dorosłych.

Monografia ma czytelną strukturę. Składa się z czterech części, składających się w zamierzeniach autorów na wieloaspektowe studium porządkujące zagadnienia ważne dla praktyki edukacyjnej.

Część pierwsza przedstawia idee edukacji całożyciowej w kontekstach i perspektywach różnych koncepcji badawczych. W artykule wprowadzającym E. Solarczyk-Ambrozik (redaktorka recenzowanej publikacji) zaprezentowała współczesne tendencje w kształceniu ustawicznym wynikające z przemian w perspektywie globalnej, a także te, które są konsekwencją kluczowych kierunków europejskiej polityki wobec edukacji i kształcenia ustawicznego. Autorka pisze o konsekwencjach dla praktyki edukacji dorosłych na różnych poziomach i w różnych formach organizacyjnych. Wskazuje na problemy, które w niedalekiej przyszłości stanowić będą punkt odniesienia zarówno dla rozważań teoretycznych, projektów badawczych, jak i praktyki edukacyjnej. B. Śliwerski porusza w swoim artykule problem samowychowania jako jednego z rodzajów uczenia się przez całe życie. Problem, który kumuluje w sobie cały szereg nierozstrzygniętych dotychczas spraw spornych między badaczami zachowań ludzkich dotyczących klasycznych anty- 
nomii: wolności i przymusu, indywidualizacji i uspołecznienia, świadomości i nieświadomości oraz intencjonalności i przypadkowości. W związku z tym kontrowersyjne i wciąż niejednolite jest zdaniem Autora rozumienie pojęcia „samowychowanie” w naukach pedagogicznych. J. Kargul zaproponował analizę edukacji dorosłych w perspektywie kultury pośpiechu. W swoim tekście dokonał charakterystyki cech tej kultury, wskazał na ich konsekwencje dla uczenia się, a szczególnie uczenia się dorosłych. Kolejny artykuł w tej części publikacji autorstwa H. Solarczyk-Szwec pt.: Polifonia czy kakofonia znaczeń edukacji ustawicznej? omawia zagadnienia związane ze zróżnicowaniem treściowym pojęcia „edukacja ustawiczna” i z konsekwencjami tego zjawiska zarówno dla teorii, jak i praktyki. O całożyciowym uczeniu się z perspektywy wielokulturowych problemów współczesności (stanu tożsamościowego rozchwiania i niepewności) pisze w swoim tekście J. Semków. Problem edukacji i autoedukacji został poruszony w artykule D. Jankowskiego. Strategie rozwoju edukacji dorosłych w kontekście Kongresu UNESCO Confintea VI to artykuł H. Bednarczyka, w którym zaprezentowane zostały główne założenia i wnioski z szóstej konferencji Confintea, która odbyła się w grudniu 2009 roku w Brazylii. Część pierwszą pracy zamyka tekst J. Stochmiałka, wskazującego na znaczenie całożyciowego uczenia się w przezwyciężaniu wybranych kryzysów życiowych.

Druga część dotyczy specyficznej „przestrzeni”, jaką jest uniwersytet. W tej części teksty skupione są wokół przestawienia wielowymiarowości edukacji uniwersyteckiej. Z. Melosik omówił w swoim artykule znaczenie i funkcje dyplomu akademickiego oraz wskazał na społeczne rekonstrukcje sukcesu życiowego. E. Skibińska zaproponowała refleksję nad andragogiczną edukacją studentów. Autorka wskazała na możliwość realizacji różnych koncepcji tej edukacji i zaakcentowała praktyczne konsekwencje wyboru poszczególnych opcji. W tekście T. Aleksander prowadzi rozważania nad specyfiką i funkcjami studiów podyplomowych. Tę formę kształcenia dorosłych Autor zaprezentował w kontekście ogólnych tendencji w koncepcji całożyciowego uczenia się. Celem artykułu A. Majewskiej-Kafarowskiej była próba pokazania, w jaki sposób współczesny uniwersytet realizuje tak ważną dzisiaj ideę edukacji całożyciowej, a dokładnie - ukazanie, iż zmiany zachodzące w uniwersytetach zmierzają w kierunku urealniania idei kształcenia ustawicznego/całożyciowego. Natomiast M. Rosalska i A. Wawrzonek kontekstem podjętych rozważań w artykule pt.: Prekariat jako wyzwanie dla doradztwa akademickiego czynią dyskusję dotyczącą nowej klasy społecznej nazwanej i zdefiniowanej przez Guya Standinga w pracy The Precariat. The New Dangerous Class. Wokół doradztwa akademickiego zbudowany jest 
także artykuł M. Bartkowiak i J. Szłapińskiej. Głównym obszarem przemyśleń zawartych $\mathrm{w}$ artykule jest ukazanie i podkreślenie znaczenia roli uczelni w przygotowaniu absolwentów do efektywnego poruszania się po rynku pracy oraz ich aktywizacji zawodowej. Uwagi na temat kształcenia ustawicznego, ze szczególnym uwzględnieniem nauczycieli, są przedstawione w tekście J. Szafran, zamykającym drugą część publikacji.

Cześć trzecia łączy się z poprzednimi, opisując związki i uwarunkowania, z jakimi mierzy się edukacja całożyciowa w konfrontacji z rygoryzmem narzuconym przez rynek pracy. Problemy podejmowane w tej części wpisują się w szeroko rozumiany obszar rynku pracy. Istotne miejsce zajęły kwestie dotyczące zróżnicowanych możliwości realizacji indywidualnych dróg do pracy i zawodu, wzajemnych relacji między wiedzą wytwarzaną przez edukacyjne systemy a wiedzą praktyczną, problemu (nie)równości kobiet w sferze zawodowej, roli wolontariatu w budowaniu i kształtowaniu społeczeństwa obywatelskiego, postakcesyjnej emigracji zarobkowej przestawionej w kontekście całożyciowego uczenia się i wreszcie kształcenia do korzystania z pieniędzy. W niniejszych artykułach autorzy Z. Wolk, S. Banaszak, A. Gromkowska-Melosik, M. Barańska, J. Kozielska, J. Wierzbicki odwołują się zarówno do koncepcji teoretycznych, jak i rozwiązań z zakresu praktyki edukacyjnej.

W ostatniej, czwartej części, zaprezentowano kilka perspektyw i egzemplifikacji idei i praktyki edukacji całożyciowej, co stanowi dopełnienie treści przedstawionych wcześniej. Egzemplifikacje idei i praktyki edukacji całożyciowej są przedstawione w tekstach: A. Stopińskiej-Pająk, T. Maliszewskiego, T. Gmerka, Z. Szaroty i A. Panek oraz S. Słowińskiej. Analizę instytucjonalnego rozwoju edukacji ustawicznej w perspektywie historycznej zaprezentowała A. Stopińska-Pająk. Autorka nie podejmuje dyskusji terminologicznej dotyczącej pojęcia edukacji ustawicznej, wskazuje jednak na obecne rozproszenie terminologiczne. Odwołując się do tradycji, ujmuje edukację ustawiczną w jej różnorodności terminologicznej, teoretycznej i praktycznej. T. Maliszewski ukierunkował swój tekst na przybliżenie czytelnikom Ignacego Solarza, jednego z głównych twórców polskich Uniwersytetów Ludowych oraz ważnego animatora edukacji dorosłych na obszarach wiejskich w okresie dwudziestolecia międzywojennego w Polsce. Autor w tekście analizuje, jak na przestrzeni kolejnych dekad kształtowało się zainteresowanie dorobkiem Solarza, i podejmuje próbę sformułowania opinii na temat tego, jak można by podtrzymać owo zainteresowanie w przyszłości. O edukacji dorosłych w Finlandii w swoim tekście pisze T. Gmerek, zaś A. Panek oraz Z. Szarota prezentują wybrane zagadnienia związane ze 
społecznym wymiarem edukacji w środowiskach lokalnych. Jest to studium przypadku gminy Zakliczyn jako terenu edukacji społecznej. Koncepcję edukacji międzygeneracyjnej w niemieckiej teorii i praktyce opisuje S. Słowińska. Podkreśla, iż potrzeba wprowadzenia uczenia się międzygeneracyjnego do edukacji dorosłych uzasadniana jest dokonującymi się w niemieckim społeczeństwie przemianami demograficznymi, gospodarczymi, społecznymi. Natomiast w tekstach: W. Jamrożka i K. Jakubiaka, B. Cyboran, D. Gierszewski, B. Boczukowej i R. Koniecznej-Woźniak zaprezentowano możliwe perspektywy dla rozwoju idei i praktyki edukacji całożyciowej. W. Jamrożek i K. Jakubiak uczynili swój artykuł wprowadzeniem do dyskusji na temat idei edukacji ustawicznej w europejskiej i polskiej tradycji edukacyjnej. B. Cyboran przedstawiła studium z zakresu polityki lokalnej. W swoim artykule dokonała analizy lokalnych strategii rozwoju w celu rozpoznania, jakie miejsce i jaką rolę lokalni politycy przypisują kształceniu ustawicznemu w procesie wzmacniania rozwoju społeczności lokalnych. D. Gierszewski pisze o perspektywach edukacji w ramach ekonomii społecznej. Tematyce regionalizmu poświęcony został artykuł B. Boczukowej. która wskazuje, że zagadnienia regionalne związane z kontekstem życia grup i jednostek powinny być uwzględniane $\mathrm{w}$ propozycjach edukacyjnych dla dorosłych. R. Konieczna-Woźniak przekonuje, że edukacja seniorów jest jedną z bardziej skutecznych strategii pozytywnego starzenia się. Przemiany XXI wieku doprowadziły do tego, iż mimo braku formalnej „szkoły starości”, samo życie i jego różnorodne konteksty dają szansę uczenia się pozytywnej, satysfakcjonującej starości.

Zgromadzony w omawianej publikacji materiał pokazuje różnorodność zagadnień związanych z tak niezwykle nośną ideą edukacyjną, jaką jest całożyciowe uczenie się. Rozmiar i zawartość merytoryczna pracy oraz związany z tym wysiłek wszystkich autorów artykułów i redaktorki publikacji, przekładają się na jej wartość naukową.

Wielowątkowe dyskursy dotyczące uczenia się przez całe życie inicjują konieczność krytycznego namysłu i krytycznej refleksji nad omawianą problematyką i stawiania pytań generujących dalsze poszukiwania badawcze w tym zakresie. O walorach recenzowanej monografii stanowią głównie aktualność podjętej problematyki oraz interesująca treść prezentowanego tekstu.

Anna Matusiak 